\title{
Tekdüze Yaşamın Metafizik Şiddeti: Torino Atı
}

\author{
Prof Dr. Hüseyin KÖSE \\ Yrd. Doç. Dr. Ömer ALANKA
}

atatürk üniversitesi, iletişim fakültesi

hkose@atauni.edu.tr

omer.alanka@atauni.edu.tr

\section{Abstract \\ The Metaphysical Violence of Monotonous Life: Turin Horse}

When Nietzsche sees a horse being whipped in Torino, he hugs the horse and puts himself on the ground. After such an experience going insane, he becomes bedridden for 10 years and dies. Béla Tarr, in his movie Turin Horse (A Torinoi Lo, 2011), he aims at showing the metaphysical intensity of a monotonous life of a silent daughter and a crippled father after asking the question "What happened to the horse?" It seems that the first philosophical and ontological questions that are raised by the Turin Horse find their answers in Cioran, Bachelard and mysticism besides Nietzsche. In this research, the deeper meanings of "Nietzsche Horse", along with the beliefs of the many named scholars, are studied in the eschatological movie of Béla Tarr. When we talk about the image of wind in the movie, we see that it turns everything it touches into nullity and ontological silence, and God's absolute resolution. It will make us move in force. In that sense, what is living in force despite everything? What does trying to make us believe in ourselves that we are carrying on living without validating the values trampled in Nietzsche's Horse mean? And finally, isn't it weird to resist the metaphysical intensity of life conditions that we are obliged to? The possible answers will be provided for those questions in the course of our treatment of the subject matter.

keywords: the turin horse, ontological solitary, monotonous life, metaphysical intensity of life 


\section{Résumé}

\section{La violence metaphysique de la vie monotone: Cheval de turin}

Nietzsche voyant qu'un cheval est flagellé à Turin, enlace l'animal et sanglote. Nietzsche qui perd la raison après cet événement, vit cloué au lit au cours d'onze années et meurt en devenant fou. Dans le film, Béla Tarr demande la question "Qu'est-ce qu'il arrive au cheval?" dans le film de Cheval de Turin (A Torinoi Lo, 2011) et se met à suivre les traces de la violence métaphysique des vies monotones d'un père handicapé et sa fille taciturne avec "ce" cheval dans une cabane isolée. Le philosophe allemand témoigne d'humiliation de toutes les valeurs humaines à l'existence de ce cheval. Les études philosophiques et ontologiques qui sont suggérées de première main au Cheval de Turin, trouvent leurs équivalences dans la croyance de Cioran, Bachelard et (dans le cadre de mysticisme oriental) Tasavvuf en sus de Nietzsche. Dans le cadre des études notionnelles prévues par les croyances et penseurs mentionnés, les couches de sens de la métaphore de "Le Cheval de Nietzsche" s'analysent dans le contexte de film eschatologique de Béla Tarr. Quant à l'image de de vent dans le film, il transforme toutes les surfaces qu'il touche en l'harmonie étrange de la solitude ontologique et du néant et en l'élégie de la désintégration de façon absolue des valeurs et de Dieu. Le vent nous portera et nous déplacerons forcément. En ce cas, malgré tout, qu'est-ce que vivre "bien qu'il est dur " signifie? Qu'estce que "essayer de convaincre nous de vivre sans valider les valeurs foulées sur aux pieds dans l'identité du Cheval de Nietzsche " signifie? Et en outre, si être contraint à vivre n'est pas l'acquiescement de la violence métaphysique de la présence récurrente, qu'est-ce qu'il est? Dans l'étude, les traces de ces questions et des questions semblables sont suivies.

mots-clés : cheval de turin, solitude ontologique, monotonie de l'existence, violence métaphysique de vivre

\section{Özet}

Torino'da bir atın kırbaçlandığını gören Nietzsche, ata sarılır ve ağlayarak yere kapaklanır. Bu olaydan sonra akli dengesini kaybeden Nietzsche, on bir yıl boyunca yatalak olarak yaşar ve sonrasında da çıldırarak ölür. Bela Tarr, Torino Atı (A Torinói Ló, 2011) isimli filminde "Peki ata ne oldu?" sorusunu sorar ve filmde, gözlerden uzak bir kulübede muhtemelen Alman filozofun onun varlığında tüm insanlık değerlerinin aşağılanmasına tanık olduğu "o" atla birlikte, kötürüm bir baba ve suskun kızının tekdüze hayatlarının metafizik şiddetinin izini sürmeye koyulur. Torino Atı'nın ilk elden çağrıştırdığı felsefi ve ontolojik irdelemeler, karşılıklarını Nietzsche'ye ek olarak, Cioran, Bachelard ve (Doğu mistisizmi bağlamında ise) Tasavvuf itikadında buluyor gibidir. Bu çalışmada, adı geçen düşünürler ve inanışların öngördüğü kavramsal irdelemeler çerçevesinde "Nietzsche Atı" metaforunun anlam katmanları Bela Tarr'ın eskatolojik filmi bağlamında çözümlenmektedir. Filmdeki rüzgâr imgesine gelince; değdiği her yüzeyi hiçliğin ve ontolojik ıssızlığın ürkütücü armonisine, tanrının ve değerlerin mutlak biçimde çözülüșünün ağıtına dönüstürmektedir. Rüzgâr bizi sürükleyecek ve zorla da olsa hareket edeceğiz. Şu halde, her şeye rağmen, "zorla da olsa" yaşamak ne demektir? Nietzsche Atı'nın kimliğinde ayaklar altına alınan değerleri yeniden geçerli kılmaksızın kendimizi yașamayı sürdürdüğümüze inandırmaya çalışmak ne anlama gelmektedir? Ve dahası, yaşamaya mecbur kılınmış olmak, onun bıktırırcasına tekrar eden mevcudiyetinin metafizik şiddetine katlanmak değilse nedir? Çalışmada bu ve benzeri soruların izleri sürülmektedir.

anahtar kelimeler: torino atı, ontolojik ıssızlık, varlığın tekdüzeliği, yaşamanın metafizik şiddeti 


\section{Giriş}

Torino Atı, tıkanmıș gelecek fikrine dair bir filmdir her șeyden önce. Rutin bir hayatı, kendi imkânları dıșına hapsolmuş, anlamsal açıdan tıkanmıș bir hayatı betimler. Tekdüze bir yaşamsal ritmiğin gölgesinde, gelecek umudunun daha bugünden tükenmiş olmasına, her türlü değişim ve açılım imkânının yokluğu düșüncesine odaklanır. Filmin gergin siyah-beyaz fotoğrafisinin intiva ettiği ısrarcı karşıtlık bile, neredeyse bu anlamsal/ontolojik tükenişin doğrulanışı gibidir. Çekim planlarının normal ölçülerin çok dışına taşan uzunluğuyla daha da uzatılan sıkıntı, karakterlerin içsel ve dışsal yaşama zorluğunun dolaysız dışavurumu olarak, verili olanın zorlayıcı gücüyle güçlendirilmiş teolojik bir defansa karşılık gelir. Söz konusu zorluk, varoluşun tekinsiz imkânlar alanı içinde üretilmiş ve bizatihi onu yeniden üreten bir süreç olduğu içindir ki, hiçbir varlık -ölümü de dâhil- kendi sonlu imkânlarını borçlu olduğu koșullar üzerine düșünemez. Dahası, şayet bir biçimde geleceğin tıkanmış olduğu fikri doğruysa, hayatı istisnai durumları yöneten yıkıcı bir patafiziğin ${ }^{1}$ ya da genelleştirilmiş bir amaçsızığın tehditkâr sınırları içinde düşünmek, açıklanması son derecede zor ve içinden çıkılmaz bir muammadır. Hatta afallatıcıdır, çünkü "mevcudiyetin anlamsızlığını yaşamak kadar hiçbir şey sarsamaz insanı" (Tura 2002: 92). Torino Atı́nın alttan alta mırıldandığı anlamsızık, her şeyden önce kozmogonik bir anlamsızlıktır; mevcudiyet iddiasından önce mevcut olanın anlamsızlığıdır, filmin yaklaşık iki buçuk saat boyunca odağını asla kaybetmeden, dışarıdan gelecek her türlü beklenti ve kurtuluş ümidine kaskatı, daimi bir huzursuzluğun verilmiș onayıyla sırtını çevirmiş görünen önerisi tam da bu ölümcül hakikati anlatmakta gibidir: Kökensel bir tükeniş olarak duyumsanan çaresizliğin tıkanmış bir gelecekten başka olgunlaştıracağı hiçbir şey yoktur. Hikayenin neredeyse hareket yanılsaması veren tek imgesi olan ve yeryüzünde yarattığı telas ve kaldırdığı görkemli talanla neredeyse hayatın tüm dirimsel enerjisine galebe çalan rüzgar, taş evin içini dış dünyanın karanlık demonlarına karşı aydınlatan ve artık tükenmek üzere olan gaz lambası, bir sabah -anlamlı bir işaretmişçesine- kuruyuveren kuyu, belirsiz ancak öngörülebilir bir nedenle yemeden içmeden kesilmiş, sonraki günlerde ise tüm zorlamalara ve sıkıştırmalara rağmen gönülsüzce ahırından çıkarıımasının ardından arabaya koşulduğu her defasında yerinden bir santim dahi kıpırdamamaya yemin etmiş gibi davranan at, bir sabah adeta vakitsiz bir çengi içinde uzaklardan çıkagelerek uğursuz ve tacizkâr tiratlarıyla ortalığı velveleye verip geldikleri gibi savuşan çingeneler ve nihayet altıncı günün sonunda ocaktaki son ateş közünün de ansızın sönüp gidişiyle birlikte pişirilmeden "yenmek zorunda kalınan" patateslerin baba-kız çiftinin kesinleşmiş akıbetine ilişkin yönelttiği irkiltici ikaz, v.s... Tüm bunlar, Tanrı'nın azgın demonlarını yeryüzünün dört bir köşesine salmış olduğunun kanıtlarıdır. Dolayısıyla artık "karanlığı durdurmak" imkânsızdır. Şayet

1 Patafizik: Metafizik ötesi âlemi konu edinen istisnalar bilimidir. Patafiziğin çalışma alanı genellikle psödofelsefe (sahte felsefe) özellikler taşıyan konularla bağlantılıdır. İlk olarak Alfred Jarry'nin kullandığı patafizik kavramı, modern bilim ve yöntemlerin ironik bir dille hicvedilmesi amacını taşımaktadır. "insan olmak", Nancy'nin dediği gibi, "basitçe bir insan olmaktan sonsuzca daha fazlasını olmaya açık olmak"sa (2011: 31), bu açıklığın daha da daraltılmış, amansız bir parabole dönüștüğü an gelmiștir. "Nietzsche Atı" sonrasının insanlık anlatısının özü budur; "ümit ișkencesi"ne son vererek kendi de son bulmuş bir hayat, geriye kalan son ışık parçası ve esenlik kırıntısı içinde, "her şeyi ifade etmiş olduğundan ifadesiz kalmış" (Cioran 1999: 7) bir ağız... Kuyunun söylediği belki de budur, tüm diğer tükenmiș șeylerin tükenmiș olmakla söyledikleri șey budur. Hikâyenin sade ve dolaysız anlatımının hiçbir yanlış anlamaya, fazladan hiçbir dil çatallanmasına mahal vermeyen yönü budur: Melun bir tükeniş! Hiç kimse masun değildir bundan; ne sarsılmaz bir hakikatin harikası gibi yola düzülenler, ne "imkânsızın büyüsüyle harekete geçen" (Cioran 1999: 82) büyülenmişler, ne de gördügü düşleri bir sayıklamanın alt metninden ayırt edemedikleri için ilkinden daha azaplı bir sona mahkûm olanlar... Hiç kimse... Bu yüzdendir ki, Bela Tarr'ın kahramanları, daha ilk andan itibaren içine uyandıkları o büyük geceyle birlikte -mademki Nietzsche Atı'nın tarifsiz ıstırabına gönüllü yataklık etmişlerdir-, bu saydıklarımızın hepsinden daha uyanık bir bilince ve asıl büyük hakikate ilişkin sarsıcı bir farkındalığa sahiptirler: "Dünyaya yeni bir sayıklama lazım[dır], aksi takdirde hareketsiz kalıp taşlaşacaktır" (Cioran 1999: 16). Şu halde Torino Atı'nın tam da bu bağlamda, taşlaşmış bir dünyanın öykülemesi olmadığını kim iddia edebilir? Kendi yüzeyselliği içinde taşlaşmış bir hayatın tekdüzelikten mürekkep cehenneminin şiddeti olmadığını? Evrenin gözden uzak, ıssız bir bölgesinden, ruhun çorak mıntıkasından el eden de bu her şeyi birbirinin anlamsal ufkuna içi boș sonsuzluğuna indirgeyerek genel bir sayıklamaya dönüștüren tekdüzelik cehennemi değil midir? Su halde, örselenmiş benlikleri ufalayıcı bir gerçeklik sayıklamasını tekdüzeliğin cehennemine dönüştüren bu fasit yaşamsal daireden başlamak gerek söze ilkin; başka bir deyişle, tekdüzeliğin metafizik şiddetinden.. Hiç kuşkusuz, siddetin metafiziğini yapmaktan daha muteber ve șimdiye dek fazla tanık olmadığımız düşünsel bir ufka açacaktır bizi böylesi bir sorgulama; kim bilir ya da belki Kamper'in dediği anlamda "kaybolmanın ufku"na (Akt. Baudrillard 2006: 52) getirip bırakacaktır. Ama her ne olursa olsun, belirsizliğin teması ya da metafizik olanın şiddeti, fiziksel olanın maddi şiddetinden görünmezliği ölçüsünde daha da yıkıcı olacaktır.

\section{Tekdüzeliğin Metafizik Şiddeti}

Burada şunu hemen belirtelim ki, tekdüze yaşamanın metafizik şiddeti üzerine herhangi bir muhakemeye girişmeden önce, yüzeysel genellemecilik iblisinin kurduğu tuzaklara kolayca düşmemek, uyanık bilincin temkinli/derinlikli düşüncesi adına şu mühim ayrımı yapmak gerekir öncelikle: Yaşamın metafizik şiddeti içerdiği olanca müphemlikle birlikte, hemen her zaman Batı'yı sendelettiğ ölçüde Doğu'yu telkin edici bir sarahatle diriltmiştir. Algılanabilir gerçekliğin idraki, ilkinde engin bir kesinlik duygusunda son bulurken; ikincisinde, en bulanık düşlemlerin -deyim yerindeyse- "gizli ilimler" hazinesinde soluklanmıştır. Ilki, kavrama gücünün gizil olanı algıdan kovan seslerine; ikincisi, tamı tamına gündelik olanın içe patlamış ruhaniliğine karşıık gelir. IIlkinde algının imkanları 
görünür evrenin ve dünyeviliğin ampirik sınırlarında, ikincisinde görülene karşıık hissedileni öne çıkaran rahmani duyarlık mertebelerinde ifadesini bulur. İki algının ve anlamın, ikincisi idrakin kapılarını zorlar. İlki fenomenolojik berraklığın Husserlci terasıyken; ikincisi sarhoşluğun ve buğulu vecit hallerinin Ömer Hayyam katıdır. Hayatın çelişkilerle yüklü zenginliğini ve derinliğini yozlaştıran da varoluș karmaşasının donuk bir ideal içinde bu şekliyle mutlaklaștırılmasıdır iște... Bașka bir deyişle, Heidegger'e öykünerek söylersek, hayatın "hergünkülük" harabelerinin içerdiği mucizevi olanakların baştan sona yanlış kavranışının bir sonucu olarak, görünen yüzeyinin müptezellikle birbirine karıştırılması değil midir söz konusu indirgemecilik? Yaşamın noksanlığı, sonluluğu, kusurluluğu ve bitap düşürücü niteliği onun her gün yeni bir bahaneyle ve yeniden tekrar edebilmesinin temel koşulu, mutlak gerekçesiyse eğer, art arda eklemlenen günlere yadsımanın diliyle çöreklenen de bu öngörülebilir ve bildik tekrarları değil midir her günkü var oluşun? Torino Atı'nın hergünkülüğün șiddetiyle tökezlettiği izleyici, kend hayatına ilişkin sır perdelerinin ardındaki derin boşluğu gördüğünde, hiçbir esaslı var olma tecrübesinin yüceltimine de bel bağlayamayacaktır artık. Çünkü sır, onu gizlediği varsayılan perdenin var oluşun tüm zamanlarında yalanladığı bir hiçlik, içi sahte ve yaban sesler, yankılarla dolu bir avuntudan başka nedir ki? Cioran'ın da vurguladığı gibi, adına hayat dediğimiz o birbirini izleyen anlar boyunca "sersem bir algıya hapsolmuşçasına" seyre daldığımız şey, o anların her birinin "bir kapsamları ya da bir anlamları" olduğu yanılsamasıdır sadece (2008: 17). Bu anlamda "hergünkülüguün" yüzlerimize vuran göz kamaştırıcı ışığının mucizevi başlangıcından başka sır yoktur... Bu öylesine canlı bir mucizedir ki, ilgi bekler; sıkıntıya komşu bir ihtimamdan beslenir, her günü yaşama ve hergünkülüğün bıktırıcı tekrarlarıyla başa çıkma zorunluluğunun kapıyı içeriden kilitleten görkemli kabullenilmişliğini getirir; tartışmasız, berrak bir onayın verilişiyle birlikte de kusurlu yüceliğini edinir yersiz büyüklenmelerimiz, șssinmelerimiz arasında. Bu yüzdendir ki, hergünkülük mucizesi, kendi körelmiş zevklerinin ümitvar toprağında sınanır. Filmin siyah beyazla somutlaştırdığı berraklık, yine bu anlamda her günkü yaşamı dölleyen ümitsizliğin uğursuz zigotu gibidir. Bir şeyler devam etmemeye devam edecektir, gün dönümleri ve mevsimler, haftanın her biri farklı bir gökkuşağı rengine çalan günleri birbirini izliyormuş taklidi yapacak, sabah kalkıldığında önce yataklar yapılacak, her gün bir önceki günün intikamını alırcasına biraz daha umutlu ve hırslı olunacak, yarınların getireceği muhayyel mutluluk ve zenginlikler hep bir sonraki daha büyük mutluluklar ve zenginlikler için görülecek büyük düşlere gizlice ertelenerek yaşanacaktır... Tarr'ın filminde vahameti koşulsuzca onaylanan şey budur işte. Her sabah kötürüm bir babayı ıssızlığın körelmiş diliyle giydiren genç kızın yine aynı uğursuzluğun dilini kullanarak, kulübenin içinde de tıpkı dışındakine benzer biçimde inzivai çemberler oluşturması, gündelik olanın sıradanlığının kabullenilmiş acısına karşı kişiyi en iyimser tahminle bağışık kılar. Buna karşılık, "beklenmedik tek bir olayın hala yolunu gözleyen kişi" (Cioran 2008: 77) ise, asla erişemez böyle bir selamete. Vasatı, sıradan olanı mutlak boyun eğişle tescilleyen selamete erme düşüncesi, vazgeçmeler dünyasının huzur telkin eden iniltisidir. Filmin gerçek trajik kahramanı olan ata gelince; daha ilk sahneden itibaren bu dünyaya fırlatılmışlığımızın ve terk edilmişliğimizin süregiden lanetli imagosu olarak çarpar gözümüze İndirgenmez alteritesinin gizemi ve suskun 'öznelliğiyle', insan oluşa karşıtlığıyla öne çıkan hayvan, sonunda beslenmeyi ve çalışmayı tümden bıraktığında, "bu katı reddiye", Reginer'nin dediği gibi (2011), "güç istencinin, dolayısıyla tüm insani girișimin boşunalığını telkin edercesine Nietzsche'nin meşum hikâyesini yankılar kulağımıza." İnsanlığa ilişkin idealler evreni atla birlikte kopkoyu bir suskunluğa gömülürken, ufukta onun yerini alan sey, ezeli inançsızlık ve güvensizliğin ruhun ISsız çölünün ortasında belirişidir birden bire. Bu durum, filmde az sayıda insanın yaşadığı rüzgârlı ve metruk bir kırsal bölgeyle anlatıır. Tükeniş, rüzgârın hiç dinmeyen uğultusunun yarattığ görsel burgaçların canlılığında daha hissedilir bir çaresizliğe dönüşür. Ahır kapıs dışarıdan atın üzerine kapanırken, adeta biz de onunla birlikte içeride, karanlığın içinde kalakalırız, sanki melun bir dünyanın içine hapsedilmişiz gibi..

Filmde bir "iç"e hapsolmușluğun çeșitli düzeydeki imleri açıkça gösterilir: Israrcı rüzgârın kendi içlerine hapsettiği baba-kız, ilk önce çingenelerin gelişiyle birlikte yaratılan tedirgin edici beklenmediklik doğrultusunda yaşama coşkularının tükenmișliğiyle yüzleșir. Ardından yine aynı meșum görünüșlü çingenelerin kimliğinde dış dünyanın devinim ve canlılığıyla "iç"eriye taşıdıkları ölçüsüz neşenin sataşan ve acıtan yönüyle. Dahası, yaşlı çingene, ödünç aldıkları "suya karşılık" kızın eline -sonradan İncil olduğu anlașılan- bir kitap tutușturmuștur. Kitabın eve girişiyle birlikte, adeta nifak tohumu da saçılmış olur; çünkü bu olayın hemen akabinde kuyunun kuruması, evi aydınlatan ışığın tükenişi, yaşamı besleyen yenileyici ateşin, ocaktaki en son köz parçasının da sönmesi tuhaf biçimde aynı zamana denk gelir. Peki ama bu durumu nasıl okumak gerekir? Incil aracılığıyla, Tanrı kelamının kızın ona temas etmesiyle birlikte geriye kalan son yaşam pırılılarını da yok etmesi olarak mı anlamalıdır? Kitap, şayet alınan suyun karşılığında verilmişse, Incil'in mümin ruhlara hayat veren gücüyle kıyaslandığında, kitabın kurumuş kuyunun besleyici suyuna tercüme edilmesi mümkün müdür? Yoksa kuyunun kuruması, metaforik olarak yaşama enerjisinin sonrasız biçimde geri çekilmesi midir? Eğer öyleyse, yani Incil bir biçimde kurumuș kuyunun suyunu ikame ediyorsa, baba-kızın dikkatinin dünyevi olandan uhrevi olana yöneltilmek istenmesine mi karşılık gelmektedir bu? Artık hayat veren su yok, onun yerine her soruya verecek bir cevabı olan Tanrı kelamı var, vs... Tüm bunlar olabilir. Ancak Incil'in filmde sadece bir yerde, o da genç kız tarafından kekeme bir sekilde bin bir zorlukla okunmaya çalışıldığını gördüğümüzde, özellikle kekemelik açısından bu görüntüsel göstergeye farklı bir anlam yüklemek gerektiğini de anlarız. Nitekim Freudyen kuram baba yasası ya da Tanrı yasası karşısında insanın dilinin tutulup kekeme kalmasını Hz. Musa örneği ile açıklamaktadır. Tanrı'yı görmek isteyen ve gören Hz. Musa kekeme kalmıştır. Aynı şekilde, psikanalitik kuram otoriter baba figürüne sahip çocuklarda kekemelik semptomunun görüldüğünü söyler. Bu bağlamda baba yasası veya Tanrı yasası aynı etkiye sahiptir. Bu önemli ayrıntıy aklımızın bir kenarında tutarak yukarıda sorduğumuz soruları bir tek dairesel çerçeve içinde yanıtlamaya çalışırsak, çok genel olarak ve mutlak biçimde negatif bir anlam yüklenebilirmis gibi geliyor İncil'e: Anti-Incil ya da "tersinden yazılmış Incil" ya da "müellifi İblis olan İncil", vb. Şayet felaket koşullarında bulunmuş ve 
bir biçimde temas edildiği halde malum felaket ortadan kalkmamışsa, dahası, işler daha da vahim bir hal almışsa, Tanrı kelamının kötülük karşısında aciz kalması demek olmuyor mu bu? Bu ve benzeri sorgulamalar, meseleyi kolayca içinden çıkılamayacak teolojik mülahazalar alanına taşıyacaktır besbelli. O yüzden iyisi mi biz şimdilik bu manidar şüpheyle yetinelim yalnızca.

Nietzsche şöyle yazıyor Zerdüșt Böyle Diyordu isimli başyapıtının bir yerinde: "Niceleri çöle gidip kendi canlarına kıymışlardır, erdemlerinin savaşı ve savaş meydanı olmaktan bıktıkları için" (Nietzsche 2008: 42). Kuşkusuz babakızın ahvaline acıklı bir anıștırma olarak okuyabiliriz bu saptamayı. Gerçekten de Torino Atı'nın kahramanları, bilinç düzeyinde ölmüş, yarı yarıya kendi canlarına kendi elleriyle kıymış kimselerdir. Filozofun deyimiyle, baba-kız, erdemlerinin savaș alanında can vermektense, "kendi dallarında asılı kalmıșlar"dır uzun süre (Nietzsche 2008: 72). Çünkü büyük insanlık ailesi, kendi erdemleri için verdiği savaşı yirminci yüzyılın yaklaşan ufkuyla birlikte daha girişmeden yitirmiştir. Savaş yitirilmiş ve ortada savaș alanının yıkıntıları kalmıştır sadece. Bir zamanların büyük ideallerinin ve yüce olan şeylerinin yerine vasatlıkta birbiriyle yarışanların ölmüş ruhları... Varlık da bu bağlamda vasatlığın sularında özünü yitirmiştir. Heidegger ünlü yapıtı Varlık ve Zaman'da şöyle yazar: "Herkesin varlığı, özü gereği vasatlığa dayanır (...) Neye cesaret edilip edilemeyeceğinin sınırların önceden çizen bu vasatıı, öne fırlayacak her istisnaya karşı müteyakkızdır. Her önce gelim sessizce bastırılmaktadır. Asli olan her şey bir gecede çoktan bilinir hale getirilerek carileștirilir" (2008: 134). İște Torino Atı, tam da bu anlamda carileştirilmiş anların mutlak biçimde hükümsüz kılınışını hecelemekte gibidir. Varlığın öncelikli mertebesi hükümsüz kılınmıştır. Artık insanın duyarlıklar alanının kışkırtıcı ürperişlerine rehberlik eden güdü ruhsal varlığı değil, gündelik işlemlerin cariliğidir. Dolayısıyla sıradanlığın her türlü farklılık arayıșı ve iddiasını da bertaraf ettiği bir durumdur bu. Çünkü artık "dasein'ın hergünkülüğü içinde neredeyse her şey, kimse değil demek zorunda kaldıklarımız tarafından yapılagelmektedir" (Heidegger 2008: 134). Bu sonuncu durumda, yaratıcı duyarlığın kendinden geçiş ve vecit halleri içinde birbirinden ayrıştırdığı özgünlüğü özdeşliğin gücü hiçleștirir. Bundan başka türlü de olamazdı zaten. Nitekim Heidegger'in deyişiyle, "dünyaiçinde-varoluş, onun hergünkülüğü ve vasatlığı içinde görünür kılınmıştır" (2008: 136). Su halde söz konusu dünyevi vasatlık, dünya-içinde-varoluș'un Nietzsche Atı'nın gözünden görünür kılınışından başka ne olabilir? Yaşlı adam atı defalarca kamçılar, ancak at ilerlemez; hiçbir şey bu isteksizliği bertaraf etmeye yetmez, hiçbir güç onu kıpırdatmaya fayda etmez. Bunun üzerine genç kız atı yeniden ahıra kapatır, ancak bu olağanüstü değerli sahnede can alıcı bir ayrıntı vardır: Kızın ahırı kapatışı, yukarıda da değindiğimiz gibi, ahırın içinden, atın gözünden verilir; bir anlamda kapı biz seyircilerin üzerine kapatılır. Ve böylece biz insanlar sessizlik ve karanlık içinde soluyan atın heyulamsı gerçekliğiyle baş başa kalırız. Dünyaiçinde-varoluşumuzun çaresizce vasatlığını tecrübe edişimizin acısı bundan daha iyi anlatılamazdı gerçekten de. Kapı, atı olduğu kadar bizi de, eyleme gücünü yitirdiğimiz bir hayatın akıp giden ritminden mahrum bırakmıștır. Sonuç: At'la birlikteyizdir, dahası onun ta kendisiyizdir (Morice 2013). Dahası, bu beklenmedik ve tehlikeli özdeşleșme, içeriden kapatılan kapıyı tüm insanlık için aniden hiçliğe açılan bir kapıya dönüştürür. Atın yaşamdan geriye çekilişi, deyim yerindeyse, tüm insanlığı, kırsaldaki "çiftliği", yaşlı adam ve kızını da bir anda hiçleștirerek varlıklarını adeta gereksiz kılar. Kısaca, kırsal bir yașam, at olmadan hiçbir șeydir. Atın suskunluğuna gelince; söz konusu suskunluk Nietzsche'nin kimliğinde insanlığın afazik öyküsünü yankılar. Filmin başında etkili bir görüntünün daha da anlașılır kıldığı duru bir dış-ses eșliğinde sunulan anekdot da, yaklaşık iki saat yirmi altı dakika boyunca hikâyenin üzerinde asılı duran tehditkâr gölgeyi anlaml kılar. Peki ama atı dövmek ne demektir? Şimdi hikâyeyi başlatan metin-dışı itkiye geri dönüp bu uğursuz eylemin kışkırttığı lanetin izini sürmeye çalışalım.

\section{“Atı Dövmek" Ne Demek?}

Jacques Derrida L'Animal que donc je suis'de söyle yazar: "Nietzsche dövülen bir atın yanında ağlamak için yeterince çılgındı. Bazen onu böyle bir hayvana binerken gördüğümü hayal ediyorum, atı kendi mahremiyetinin tanığ olarak gösterirken..." (Http://www.lesinrocks.com, 18.12.2013). At, mahreme tanıklığın tıkanmış yolu mudur? Ebedi, kııılgan hayatın kapkaranlık sonu mu? Insani varoluşun telafi edilemez yaralanmışlığı mı yoksa? Belki de hepsi... Bu, hem hikâyemizin sıra dışı kahramanı olan atın, hem de savunmasız bir canlıya karşı basbayağı fiziksel bir şiddete başvurarak kendi zayıflığının kurbanı olduğunu açığa vurmuş olan arabacının şahsında tüm insanlığın maruz bırakıldığı bir kötülüktür. Tek cümleyle; bütün insani erdemler ve özgürlügün insanın kendi güçsüzlüğü tarafından alt ediliși... Bir gün tanrısız bir dünyaya uyanılır, tıpkı susuz bir kuyunun kıyısına uyanıldığı gibi... Dövülen bir atın bakışları altında da tüm düşüncenin ölmeye başladığı bir uçurum yükselir. Bu görüntüyle birlikte, artık aşk da acıma da yok olur. Ama Tarr'ın filmi sadece bunu anlatmaz; onun anlattığı ası sarsıcı gerçek ve lanetli bir şekilde hep yeniden başlayan şey, düşüncenin ölümünün ardından, bu ölümü takip eden her şeyin yeni baştan doğuşudur: Sürekli bir fanilik duygusunu akla getiren rüzgâr, pencere karşısında gün boyu sırtı bize, yani seyirciye dönük pozisyonda oturan ve dışarıdaki yaşamsal rutinin mutat telaşını seyre dalan genç kız, adeta çaresizlikler evinin -sadece evin mi, aynı zamanda dünyanın da- suskun kiracısı gibidir. Onun bu daimi ve bıktırıc duruș içinden doğruladığı șey, takıntılı bir süreksizlik duygusunun sürekliliğidir. Bu nedenle kamera, her ne kadar kendi sürekliliği içindeki hayatı yakalamaya çalışsa da, bu birleştirici ve bütünleştirici teknik çaba kesinlikle içsel kırılma ve kopuş anlarını onarıcı bir işlev görmez. Mutlak biçimde onarılamaz olan, ayn zamanda içsel yaşantının ilelebet yitirilmiş coşkusudur. Aradan çekilen Tanrı'nın geri çekilişiyle birlikte gökyüzünde açtığı ve hiçbir karanlığın kapsayamayacağ genişlikteki bir boşluk... Her yerde, yok olan aşka ve acımaya duyulan sarsıc inancın düșmüs meleğinin hayaletiyle hüküm sürdüğü bir Tanrısızık... Levinas'ın dediği gibi, “Tanrı'nın öldüğü düşüncesi, belki de, sonsuz çeşitlemeler yoluyla çoğalan ve genişleyen bu tekdüzeliği ve kendi özdeşliğinde sakin kalmaktan aciz Ben'i ifade eder" (2011: 45). "Kendi özdeșliğinde sakin kalmaktan aciz bir Ben" Sükûnetini aciziyetine borçlu olan bir ben... Sükûneti içindeyken bile acizliği 
gereksinen bir ben... Ben'in her türlü imkânlar varyasyonunun sonu... Tanrı'nın insanlığın tinindeki ölümü bundan daha iyi anlatılamazdı kesinlikle... Ne var ki, peş peşe atın yüzüne inen kırbacı gölgesiyle birlikte kavrayan el de, acizliğin eli...

Bir kez sözün tınısının yerini kırbacın uğuldayan sesi aldığında, sessizliğin metruk dili içinde boğulmaktan gayrı bir çıkış yolu olabilir mi? İşte Tarr'ın kahramanları da benzer bir ruhani/maşeri sessizliğin içinde, "anımsamaya karşı unutuş" içinde, "bir seyin bekleniși olmayan bekleyiss" içinde (Levinas 2011: 52), "bir odaya kapatılmış iki varlık [olarak], onları çok fazla yaklaştıran ya da ayıran bir yazgı ile bir çıkış yolu bulmak için, savaşırlar" (Levinas 2011: 57). Burada, kırbacın somut gerçekliğinde, sesi uğultusundan ayıran kör bir bilinçle karşı karşıyayız. Yani yine Levinas'a öykünerek söylersek, kırbaçla birlikte etkisi hissedilen şey "gizlerini açmış olan sestir, onun söylediği şey değil" (Levinas 2011: 56). Ve giz, suskunluğun çok dilli gramerine göre, her koşulda yanıtsız olandır. Bu nedenledir ki, parmakları yakan haşlanmış patatesler, adeta yaşamı yenileyici ateşi canlı tutma girişiminin her defasında boşa çıkarılmış mecazı gibidir. Tekdüzeliğin soğukluğunun karşısına konmuş dengeleyici bir ağırlığın boşluğa odaklı göstereni gibi... Atın dövülüşüyle birlikte yeryüzüne inen hiçlik de böylesi bir gösterinin çaresizliğine gelip dügümlenir. Çünkü gösteri denilen şey, büyük ölçüde çaresizlik karşısında yaratılmış bir coşkudan doğar. Bir at için bunca şiddetli olan bu hiçlik gösterisi, 'aklı başında' bir insan türü için niçin geçerli olmasın? Öyleyse "Nietzsche Atı" sonrasının 'değerler' evreni ve düşüncenin giderek "insansızlaşması" da hiçliğin gösterisinden başka bir şey değildir. Düşünce ve değerlerin kendilerini anlamlı kılan içeriklerden hızla arınarak salt bir gösterenden ibaret hale gelmesi -ölümün gerçek ve simgesel anlamı dikkate alındığında-, Baudrillard'ın günümüz simülasyon çağına ilişkin şu saptamasına nasıl da benzemektedir: "Kendi gölgemizi" diye yazmaktadır düşünür, "kaybettik; yalnızca ıșık kaynağı olmadığı için değil, gölgenin yansıyabileceği zemin de olmadığı için. Öyleyse trapezcinin ağ kurması gerekmeyecek artık; düşüp ölecekleri bir zemin kalmadığına göre" (2006: 119). Mesaj yeterince anlaşılır ve açıktır; kimsenin düşüp ölebileceği bir zemin kalmamıştır, zira yaşamın ölümcül bir kayıtsızlık ve hoyratlığa meyleden tekamülüne koşut olarak, ölümü düşlemenin de deneyimlemenin de kavramsal zemini çökmüştür artık. Söz konusu çöküşle birlikte, film boyunca hareketsizliğin, belirsizliğin ve tekinsizliğin içinde adeta cllız bir mum ışığı gibi rüzgârda titreşen bir dünya ve bu hiç de güven telkin etmeyen dünyada, görünmekten aciz iki hayalet gibi baba-kızın şahsında melankolik ruhsal bir temsilin tüm görünümleri sergilenir. Üstelik filmdeki bu durağanlık, sadece bilinçlerinin değil, fiziksel mevcudiyetlerinin engellenişiyle de tutarlılık içindedir. Söz konusu engellenmeyle birlikte, baba-kız öznel konumlarını terk ederek nesneleşir. Çingeneler baba-kızın yaşadıkları kulübeye doğru yaklaştıklarında, çift derhal onları geri püskürtmeye çalışan otomatik bir refleks sergiler; çünkü hareketsizliğin içe çöreklenmiş gücü zalimdir; hareket ise tehditkâr. Gerçekten de insan güvenli mevzilerini terk ettiğinde, gündüz düzeninin parıldayan ışığı yönünde hareket ettiğinde kendini dışarının tekinsizliğinin "açık"larında bulur. Blaise Pascal'ın dediği gibi, "bütün felaketler bașımıza odamızdan dıșarıya çıktığımız için gelir." Çünkü dışarısı, dağııp gitmenin, "kendini her zaman bir gelecekte tasarlamanın" (Nancy 2012: 38), giderek kaybolmanın mekânıdır. Taş evin içi, kendisine sıkıntının yataklık ettiği tekdüzeliğin muhafaza edilmesi gereken alanıdır; biriktirilen sıkıntı evi'dir. Ve sıkıntı bir kez dış dünyanın solgun ışığının yüzeyiyle buluştuğunda, içsel hoșnutsuzluğun yarattığı baskı da ortadan kalkar ve baskının ortadan kalkışıyla birlikte -tıpkı bir mayına basıldığında olduğu gibi- insan paramparça oluverir. Çünkü bir anlamda, yaşama umudunu var eden şeydi sıkıntı. Nitekim çingenelerden biri kıza bir kitap verdiğinde, buna benzer solgun bir ışıkla yüzleşilir; umuda gölgelik eden sıkıntı yeniden yeşerir, kitaptaki cümleleri ancak mot-a-mot sökmeye çalışan kişi açısından çözülmeyi bekleyen hiçbir giz yoktur. Başka bir deyișle, bu dünyada tanrısal söz okunaksızdır. Onu okumaya anlamaya çalışmak boşunadır, sadece telaffuz edilen sözcüklerin tınısı işitilir taşıdıkları anlamlar değil... O halde Shopenhauer'cı anlamda büyük, kör bir iradenin egemenliğindeki bu dünya anlaşılmak için değildir, Tanrısızlığın pervasız rasgele düzeninde anlamlı görüngüler, tutarlı bütünlükler, düşsel mükemmellikler yoktur. Artık idealin boşlukta asılı duran anlamı değildir üzerinde kafa yorulması gereken, onu yersiz gürültüler içinde yeniden tasarlayan gösterilerin görüntüse öncelliğidir. Daha doğrusu, "görünüșü kurtarma"nın insanın yașadığını kendisine kanıtlamasına yettiği, "-mış" gibi yapmanın kendisiyle ve başkalarıyla ilgilenmesinin en sahte erdemine büründügü bir dünyanın acımasız ve "insansız" geleceği... Bu satırların yazarlarından biri de, Nietzsche Atı'nın muadili sayılabilecek bir örneğine, 2011 yazında İstanbul Büyükada'da, biraz da tesadüfün yardımlar sonucu kendi naçizane öznel deneyimi ölçüsünce tanıklık etmişti. Sıcak bir yaz öğleden sonrasında, faytonun önüne koşulmuş olan koyu kestane renginde bi attı. Atın diz kapağı ve sağrıları kanamıştı. Koyu renk teninde kanın berrak kırmızılığı tüm ürkütücü heybetiyle parıldamaktaydı. Ama arabacı hayvanı tedavi etmek ya da dinlendirmek yerine işe koşmaya, sırtından zalimce para kazanmaya kararlı görünüyordu hala. Ve zavallı atı o perișan hali içinde gördükten sonra acıyan bir yüreği olan hiçbir insan evladının arabasına binmeyeceğini bal gib tahmin ettiğinden, oldukça insanlık dışı, hunharca bir "çözüm" bulmuştu hayvanın "kusurunu" örtmek için: Koyu kahve tonundaki ayakkabı boyasıyla hayvanın kanayan yerlerini kapatmak! Bu ikinci eylemi ilkinden daha büyük bir insanlık faciasını gözler önüne seriyordu üstelik... Elbette binmedik, binemedik, binemezdik böyle bir atın çektiği arabaya... O haldeyken, elbette Tarr'ın yaptığ gibi, su soruyu soramazdık: "Ata musallat olan düşünce ne?" Daha çok, vicdan körelmesine uğramış o menfur arabacının şahsında uzunca bir zamandır insanlığımıza musallat olmuş olan o lanetli düşüncenin ne olduğunu düşünüyorduk... Bu, her şeyden önce uzun bir serüvendi. Torino Atı'nın özellikle yola çıkış/varış düşüncesi açısından eliptik bir geçiş olduğunu düşünenler, insanlığın vicdanına atılmış bu kör düğümü de çözmek zorunda, söylenecek tek şey bu... S. Sayet yaşam, bizi yalnızca ölüme doğru bir sona sürüklemekte ise hakikat birbirini izleyen cansız ve devinimsiz günler katarı arasında durmadan karşımıza dikilmekte ise, hayat geçip giden ve hep yeniden başlayan saatlerin her biri içinde hareketsiz ve kör bir daire çizmekte ise (Lattreille 2013), gerçekten de çözülmesi gereken bir kör düğümdür bu. Aksi halde, yine Lattreille'in belirttiğ gibi (2013), " edilgen bir acımasızıı insanı bütün insanlığın deliliğine, Nietzsche'nin 
ve Tarr'ın deliliğine götürür... Bu daimi delilik bizi durmadan kendimize, sıklıkla da bir yüzden yoksun olan kendi karanlık deliliğimize götürür." Şu halde, Tarr'ın filminin iyinin ve kötünün diline basitçe tercüme edilemeyecek niteliktek derinliğinden gücünü alan insani varoluşun tekinsiz boșluklarına musallat olmuş rahatsız edici söylemi, en azından yarattığı ürpertici atmosferin dokunaklıı̆ı açısından, varlığın yazgısal başıboşluğu düşüncesinde karşılığını bulan khora kavramıyla birlikte okunmayı da hak ediyor büyük ölçüde.

\section{Ata Musallat Olan Düşünce: Khora}

Duyumsama öncesi bir duyumsama evresinin, ontoloji-öncesi bir ilişkiler mıntıkasının varoluşsal zemini olan khora, kimilerine göre "çok karmaşık bir meseledir (...) Ne iyidir ne cömert, ne de verici. Kökten destinnerance'tır [bașıboș yazgısallık]. Onun çölüne düşen herkes kaybolur" (Kearney 2012: 243). Ezeli khora düşüncesinin Tarr'ın filmsel evreninde belirişi, tüm varlık imkânlarının tüketilerek insani hakikatin yeni baştan tasarlanmaya çalışıldığı ıssızlığın hüküm sürdüğü dilsiz bir dile karşıık gelir. Dağ kulübesinin etrafını saran ümitsiz bir boşluktur bu. Nitekim filmin tipik ikonografik bir göstereni olarak suyu çekilmiş kuyu arketipinin algılarımıza oynadığı o yaman oyuna aşina olan herkes gayet iyi bilir ki, "dipsiz kuyuların içinde [yine] dipsiz kuyular vardır, boşluktan kurtulus yoktur" (Kearney 2012: 242). Torino Atı, boșluğun kemirdiği hayatın khora'da biçimlenmiş anlatısıdır. "Boş bir uzamın boşluğu" olarak khora, evrenin kocamış kuvvetinin suyu çekilmiş ruhsal kuyusudur aynı zamanda; ruhun selametinin kökten biçimde yitirildiği, kurtarıcı ıșık yoksunluğunun karanlık haznesi... Tarr'ın filminde khora'nın karanlık mevcudiyetinin somutluğunu tescilleyen şey, dürtülerin denetiminde hüküm süren yaşamın ana koşullarına gönüllü katıımın tekdüze tekrarından bașka bir șey değildir. Şu halde, khora egemenliğinin uğursuz damgası, Tarr'ın filminin anlatı yapısına zerk edilen tekdüze yalpalamayla belli eder kendini. Khora'nın uzamı, bu anlamda, istikrarlı hale gelmiş kaosun uzamıdır. Sıkıntıya işaretli bilinci yaratan da kaotik uzamın oluş halindeki varlığıdır. Sıkıntının türediği yersiz bir yer olarak khora, filmde, izleyicinin metin dışı bilgisini temel alan Nietzsche atının serencamında boy gösterir. Başka bir deyişle, mutlak biçimde unutulması gerekli olanın tekdüze tekrarlarla sürekli yüzeye çıkmasının algıda yarattığı huzursuzlukta... Sadece huzursuzlukta mı? Aynı zamanda ebedi bir umursamazlıkta, tükenmişlikte... Çünkü metafiziğini yitirmiş, hiçbir umutlu geleceğe imkân açmayan böyle bir hatırlama, yüzeydeki trajediyi daha da derinleştirmekten bașka bir ișe yaramaz. "Zira melankolik tekrarda geçmișin hiçbir geleceği yoktur" (Kearney 2012: 218). Başka bir deyişle, şimdiki zamanın geçmişiyiz hepimiz, geçip gidiyoruz sadece, hepsi bu... Şayet anlamsız olanı hatırlamayı kışkırtan bıktırıcı tekrarlar olmasa, ahırın kapısı her açıldığında Nietzsche atının alnına vuran solgun ışığın külden yapılma bir ışık olduğu da anlaşılamazdı. Zira Freud'un dediği gibi, eğer "unutmanın en kötü biçimi tekrar"sa (Akt. Kearney 2012: 218), hatırlamanın en kötü biçimi de yine tekrardır; çünkü unutmakla bugüne mutsuzluk getirmesi muhtemel olan ezeli kötücül anıyı bastırarak hortlatılan melankoli ve onun açık tezahürü olan kaygı, hatırlamakla ve ancak hatırladıkça istikrarsız kılınır. Kaygının, her șeyi hiçbir șey olarak deneyimleyen yönüdür bu; aşırı duyarlıklı benliğin kendi içerdiği aşırııı̆a dayanamayarak maruz kaldığı bir iç patlama... Bu nedenle de mevcut olan ile namevcut olanın birbirinin yerine geçtiği, ya da Tanrı'nın ve Tanrısal vahyin kutsal olmayan bir inanç sıçramasıyla yolunu şaşırdığı bir khora fikri, Nietzsche atıyla kırılmaya uğramış, çölleşmiş bir yaşamın dilsizliğin belirsiz tehdidiyle sendeletilmesi neden olmasın? Kendine çıkıs arayan bir çığlığın, bir atın suratına inen kırbaçta yankısını bulması ise, söz konusu arayışın bir gece koşusunda son bulması demek oluyor. Tarr'ın betimlediği biçimiyle khora'nın biçimsizliğin ve kuralsızlığın belirsiz ritmi olması, neredeyse filmin bașoyuncusu olan rüzgârın diline tercüme edildiğinde, yaşamın -en iyimser tahminle- boşluğun çölünde sürüklenerek kaybolmak anlamına geldiği söylenebilir rahatılıkla. Çünkü rüzgâr yersel olana karşıtlığı içinde var olan, yersel-olmayanın sesidir. Döngüsel zamanın çileyi hatırlatan görüntüsüdür. Dahası, bir görüntü bile olmayan ürkütücü izidir onun. Rüzgâr da eğer baskın ve hatırlatıcı bir gösteren olarak Torino Atı́nın ıssız pastoral yaşamının zamanı mekândan söken hasatçısıysa, aynı zamanda gize iliškin de bir sey söylemesi gerekir. Ontoloji-öncesi duyumsamanın bulanık bir hatırası olarak giz, olup-biten her şeye ilişkin mutlak bir yanıtın yokluğu olarak, aynı zamanda hiçbir şey için hiçbir yanıta ya da hiçbir açıklamaya zorunlu bir gereksinme duymayacağımız her sey'dir. Derrida'nın deyișiyle, "giz, sözün içinde olup da söze yabancı olandır" (2008a: 59). Bu bakımdan yeryüzünde hüküm süren ve adına hayat denilen büyük telaş, boşluğun boşlukla, gizin gizle açıklanabileceği bir yerdir ancak. Bu su katılmamış dolayımsızlık, Derrida'cı giz kavramını her tür erginleșme biçiminin akamete uğratılmış doğası temelinde yeniden kurar. Daha doğrusu, her şeyin gün gibi ortada olduğu bir hayatta hemen her şey hiçliğin egemenliğine boyun eğer. Eğer hayatın makul denebilecek bir anlamı varsa, her yaşamsal edimi hiçliğe işaretleyen iște bu gizdir. "Çünkü giz olmadan, bu giz olmadan, çile yoktur; ancak bu çile olmadan giz de yoktur. Her şeyin söylendiği ve geride kalanın bir hiç olduğu yerde" (Derrida 2008a: 61) "herşeyi söyleme hakkını güvenceleyen" hiçbir șey yoktur. Giz, kendini durmadan açımlayan bir olanaktır, tam da bu yüzden, bu olanağın varlığı yüzünden "açıklanamaz." Tıpkı Béla Tarr'da her şeyin göz önünde cereyan ettiği gerçeğin bir simülakra indirgemeden anlatamayacağımız gibi... Vücudunun bir yanı felçli baba hergünkülüğün tekrarının unutmanın da hatırlamanın da sadece en kötü biçimi değil, aynı zamanda varoluşun kaçınılmaz gerçeğini benimsemenin acısın bastırmasına yardımcı olacak yegâne kurtarıcı anahtar olduğunu çözmüş olduğu için 'giz' den bağıșıktır. Filmde sıklıkla kaçınılmaz olanı kabullenișin bu acısı Macar ulusal içkisi palinka içilerek bastırıır; bu basit bir içki değildir sadece, adeta bütün bir varoluş kanamaşna karşı etkili olan bir müsekkindir. Genç kız rüzgârın (her günkü düzen tasarısını bozan gücün) ve kuyunun (her günkü yaşama istencinin) mutat fısıltısına ve sungularına așinalığıyla, yaşama telaşının önündeki tüm kuşkuları dağıtacak netlikteki yanıtlara vakıf olduğu için 'giz'den muaftır. At, her ikisinin de bu idrakini önceleyen bir zamanlamayla her şeyi unutma hakkının gize duyulan tutkuyu kışkırtan çağrısına sırtını döndüğü ve daha ilk günden itibaren hem bedeni hem de devleşen bilinci ve güdüleriyle gölgeler dünyasının bir parçası 
olmayı kabullendiği için, her türlü zorunluluktan ve edimden muaftır. Ne var ki, her üç muafiyet biçimini de hayat-olmayana benzerliğiyle, yani yaratıcı ateşin yenilenemeyiși olarak okumak ya da bununla bir tutmak ölümcül bir hatadır. Çünkü burada içselleştirildiği varsayılan çile, asla yaşamdan geriye doğru çekilişe değil; aksine, tutkuya karşılık gelir. Çünkü "giz, bizi çileyle [passion: tutku] canlandırır" (Derrida 2008a: 64). Sahtesinin gerçeğini aştığı bir dünyada, Tarr bize yenilenmiș bir giz anlatısı sunmakta. Minimalist eğilimi, siyah-beyaz fonografisinin tekinsizliğe farklı bir hava katan kontrastları ve hergünkülüguün rutinine küçük ayrıntıların soluk aldırıcı gücüyle kafa tutan "özgünlük avcılığıyla", umutsuzluğu kışkırtan gizin etkileri silinmek, ifşa edilmek șöyle dursun, derinleştirilir daha da. Başka bir deyişle, Tarr, kendisine o çok güçlü anlamlar atfedilen sıradanlığın gizini ifşa etmek suretiyle daha da derine gizler. Yönetmenin bu tutumu kurala uygundur, zira Derrida'nın dediği gibi, "giz ile de bir simülakrla, bir tuzakla, bir hileyle oynar gibi oynanabilir" (2008a: 65). Çünkü gizin diğer açıklama ve ifşa biçimlerinden farkı, bitip tükenmez, sonu gelmez bir çoğul söylem biçimine yataklık etmesidir. Giz, bilmenin meta-dilbilgisel yönünden olduğu kadar, çözümleyici aklın yorumbilgisel yönünden de yoksundur. Tarr, bu gerçeği bildiği için, giz'i ancak sözcüklerde açığa vurulabilecek, ancak aleniyet düzleminde bir anlam kazanacak, az sayıda -kopuk kopuk- diyaloga yükler. Filmde, baba-kızın ziyaretine gelen komșusuyla palinka içerek sohbet ettikleri sahnede, Haneke'nin Bilinmeyen Kod'unun filmin tüm atmosferini ele geçirmiș tekinsiz ritmini andıran ve durmadan yeni sorular, yeni soru işaretleri doğuran sözel bir salgına tanık olunur. Giz, sözcükler yardımıyla açığa vurulmaya çalışıldığında bile, belirsizliğe düğümlenir; daha doğrusu, "bir sözcükten daha fazla görünmez. Sözcük söz konusu olur olmaz doğrudan görü, artık hiçbir şansa sahip değildir" (Derrida 2008a: 65). Ziyaretçinin dediği gibi, "sanki her şey bilinmeyen bir nedenle sonsuza dek durmuş" gibidir. Tanrı ya da tanrılar yoktur, tıpkı iyi ya da kötü diye bir şey olmadığı gibi. Bunun farkına varmış olan "soylu kişiler" anladıkları şeyi anlatmakta yeterince başarılı olamamışlarsa da, anlaşılması gereken şeyi, bu dünyanın asıl gerçekliğini ölümüne bir suskunlukla ve derinden kavramışlardır... Bu kavrayışın bilgece tezahürlerinden birisi de, "ulu irtifaları mesken tutmuş" (Kearney 2012: 16) tanrılara benzer biçimde, filmin suskun evrenini boydan boya bir çıvgın gibi kuşatmış olan rüzgâr ve onun muttasıl fısıldayışlarıdır. Şu halde, hangi yönden estiğine bağlı olarak iyilikler ya da kötülükler, uğursuzluklar getiren bu rüzgârın son derecede manidar semiyolojisine ilişkin de bir şeyler söylemek gerekir.

\section{Rüzgârın Metafiziği Ya Da “Bad-ı Saba"ya Karşılık “Bad-ı Debur"}

Bilindiği üzere, Antik dönemde hava ya da rüzgâr, toprak, ateş ve su temel elementler olarak dünyanın yaratıcı maddeleri olarak görülmüştür. Rüzgâra fiziksel özelliğinin yanında tanrısal, ilham verici olduğu kadar yok edici, geçici olduğu kadar taşıyıcı birçok özellik atfedilmiştir. Rüzgârın görünmez, tahmin edilmez, güvenilmez, oyuncu, avlayıcı, yıkıcı, ilham ve hayat verici nitelikleri çoğu zaman onu hayat sahnesinin başrolüne taşımıştır. Örneğin tanrıların habercisi
Hermes şairlere ilhamını rüzgârla kulaklara fısıldar, şair gereksindiği epifaniyi bu şekilde yakalar. Bir başka örnekte ise Musa, Kızıldeniz'i şarktan esen rüzgârlar yardımıyla ikiye böler. Eski Ahit'in "Mısırdan Çıkış" başlıklı bölümünde, bu konuda şöyle denir: "Musa elini denizin üzerine uzattı. RAB bütün gece güçlü doğu rüzgârıyla suları geri itti, denizi karaya çevirdi. Sular ikiye bölündü, İsrailliler kuru toprak üzerinde yürüyerek denizi geçtiler. Sular sağlarında, sollarında onlara duvar olușturdu" (Eski Ahit, 14. Bap, 21-23. Ayetler, http://www.yaklasansaat com, 06.02.2014). Mitolojide ise Odysseus üzerindeki lanet, ordunun şehirden uygun rüzgâr bulup aylarca denize açılamaması sırasında gelir. Yunan orduları Avlid'de Truva'ya doğru yola çıkmak için toplandıklarında hiç rüzgâr olmadığı için, Agamemnon, Av Tanrıçası Artemis rüzgârları serbest bıraksın diye, kızı Iphigenia'yı kurban verir. Yine rüzgâr tanrısı Aiolos, Odysseus'a gerektiğinde kullanması için bütün fırtına rüzgârlarını içeren kocaman bir tulum hediye eder. Mitolojiden teolojiye uzanan bu anlatılarda rüzgâr, tanrısal bir güce sahiptir ve tanrılar rüzgârı bazen insanların felaketi için bazen de onlara yardım etsin diye kullanmaktadır. İlk bakışta, Torino Atı filmindeki rüzgâr da, tanrının insanlar yok etmek için aracı kıldığı bir silaha benzemektedir. Yok edici, çaresiz ruhlar daha da perişan edici, konuşkan, demonik bir rüzgar. Varlığın izi, o sahneyken, yoktur; onun bir çıvgını, yok edici bir anaforu andıran görüntüsü, yaşamın ışığ üzerine çöken bir loșluktan, ruhsal tahribatın alametlerinden birisidir. Dahası, rüzgârın karanlık metafiziğine dair ürkütücü işaretler, onun varlığının neliğine uzanan soruşturmalarla at başı gitmiştir hep. Söz konusu soruşturmalar, rüzgârın tanrısallığını da içeren bir tür palimpsestik işlemi zorunlu kılar. Nitekim Torino Atı'nın imge sarmalı bu durumu düșündürmektedir öncelikle: özellikle at, rüzgâr kulübe ve kıyamet imgeleri bağlamında. Atla başlayıp kıyamete giden sarmalda rüzgâr, sarmalın kıvrımını sağlayan müteharrik bir itki sağlamaktadır. Bu sarmala bir örnek vermek gerekirse, Hint mitolojisindeki Vayu, kimi zaman bir atın sırtında yolculuk eden, kimi zaman da bir grup atın çektiği muazzam güçteki bir arabac olan rüzgâr tanrısıdır. Savaşçı, yıkıcı, güçlü ve epik bir tanrı olan Vayu ikonografis genelde at üzerindeki bir insanla ya da at sürüsünün çektiği bir arabayla gösterilmektedir (Williams 2003: 295). Rüzgâr ve at birbirlerinin mütemmim cüzü olan iki şiirsel imge gibi birbirine yapışmıştır. Atın yeleleri rüzgârda savrulur ya da dörtnala giden atı rüzgâr taşır. Filmde apokaliptik etkiyi sağlayan şey, sürekli esen ve hayatı çölleștiren rüzgârdır. Tasavvufta batı yönünden esen rüzgâr, yani debur (Batı rüzgârı), bir yanıyla cismaniliği, diğer yanıyla da çirkin nefislerin heveslerini simgelemektedir. Eşcinsel ilişkiler yaşayan Ad kavmi, debur rüzgârıyla (Bat rüzgârı) helak edilmiștir. Öte yandan, Saba rüzgârı doğudan esen rüzgârdır ve Kabul anlamına da gelmekle birlikte, deburun aksine insana ferahlık hissi verir. Sufi inanışında debur, cismani yönlerden gelen, saba ise ruhani yönlerden gelen şeyler için kullanılır (Kaşani 2004: 243,326). Debur dekadanı, kötülüğü, ölümü ve süfli olanı; saba ise ruhani olanı, yaşamı ve yüce olanı imlemektedir. Torino Atı filminde sürekli esen bu rüzgâr, yıkımı, dekadanı, çöküşü ve ölümü imleyen debura benzemektedir. Tüm yaşam emarelerini silen ve insanın sonunu getiren bir mahiyete sahip bu rüzgâr, bir anlamda adeta ölümün sesine dönüșmektedir. $\mathrm{Bu}$ bağlamda filmde muttasıl esen rüzgâr tanrının ölümünü fısıldayıp yasını 
tutar gibidir. Filmin temel sorunsalı olan "Ata ne oldu bilmiyoruz" ifadesine gelince; Krasznahorkai'nin hikâyesine ilham vermesine karşın, yazarın hikâyeyi açıkça tarihsel olarak yeniden kurgulamamıs olduğu görülmektedir. Bizler atın kaderi ve arabacının kimliği hakkında tarihsel bir bilgiye sahip değiliz, ancak senaryo, bundan ziyade bu olayı takip eden ve dünyanın topyekûn çöküşünün meteorolojik, insani, sosyal ve apokaliptik görüntüsünü sunmakta gibidir. Filmin açılışında patetik bir dış sesle sunulan izahatta, Alman filozofun -kendisi filmde bizzat yer almamakla birlikte-, dâhil olduğu olayın senaryoya ilham vermesi söz konusudur. Krasznahorkai'nin esas hikâyesinin şablonunu oluşturan bu olay, en umutsuz, en düşük insan varlığı ile oldukça soyut, incelikli, yüce, poetik ve felsefi seviye arasındaki ikili ve karşıt ilișkiyi konu etmektedir. Bu ilișki, neredeyse Tarr'ın ikinci dönem filmlerinin tamamında yer almaktadır. Kovács, bu olayı şöyle yorumlamaktadır: "Bu hikâyede Nietzsche, yeni insan varoluş felsefesinin poetik görüntüsünü temsil ederken, kırbaçlanan at aşağılanmış, aciz ve zavallı insandan daha aşağı (subhuman) varoluşun temsiline dönüşmektedir. Bu ikisinin karşılaşması, insan olma koşullarının da hikâyesidir. Son insanla bağlantısı, final sahnesindeki aklın yitirilmesi ve kıyamet, Nietzsche'nin çıldırmasının metaforu olarak yorumlanabilir; tıpkı Nietzsche'nin içine doğan yıkımın, kıyametin ilk alameti olması gibi" (Kovács 2013: 146). Nietzsche Atı sonrasının ifade ettiği ahlaki çöküntünün hassas ruhlarda açtığı yara o denli derindir ki, olup biten şeyler rasyonel düzeni alt üst olmuş bir düşünce tarzıyla izah edilebilir ancak, yani ayan beyan ortadan kalktığı gözlenen bir yaşamsal metafiziğin yerine aynı ölçüde güçlü bir metafizik açıklama düzeni inşa edebilmekle... Bu nedenle, hikâyede Nietzsche'nin verdiği tepkiyi sadece arabacıya verilen bir tepki olarak düşünmemek gerekir; söz konusu tepki, metafiziğini yitirmiş bir insanlığın kolektif bilincinde açılmış gediğe yönelik bir tepkidir aynı zamanda. Buradan bakıldığında, atın hikâyesi de, onun kimliğinde tüm değerleri çözülmeye başlamış insanlığın onarılmaz çaresizliğiyle özdeşlik kurmuş Nietzsche'nin hikâyesidir özünde. Kovács'ı izleyerek söylersek, bir yönüyle “hikâye, Nietzsche'nin hikâyesi ile atın hikâyesinin bakışımlıı̆̆ üzerinedir. Ayrıca bu olay Nietzsche'nin ahlak anlayışının da boyutlarını yansıtmaktadır" (2013: 146).

Şu bir gerçektir ki, Batı metafiziğine kök salan ve teolojik, mitolojik öğretilerle sekillenen hayvan kavramı, içerisinde tanrının memnun edilmesine yönelik karmaşık bir ilişkiler yumağı barındırmaktadır. Derrida, bize bu noktada "ikinci orijinal günah" olarak bilinen ezeli bir cürmü hatırlatır: Kabil'in Habil'i öldürmesini. Eski Ahit'te Kabil ve Habil Âdem'in oğulları olarak gösterilir ve her ikisi de Tanrıya kurbanlar sunarlar. Kabil çiftçi olduğu için, toprak ürünlerinden bir sunu getirir, Habil ise çobandır ve sürüsünün ilk doğanlarından bazılarını ve özellikle onların yağlarını getirir. Rab, Habil'in sunusunu beğenir. Bunun üzerine Kabil çok sinirlenir ve ikinci orijinal günahı işler. Derrida'ya göre bu olayda Kabil bir hayvan gibi gölgeye saklanıp pusuya yatar ve kardeşi Kabil'i öldürür. Kabil daha sonra derin bir utanç, pişmanlık duyar. Burada ikinci orijinal günahın doğmasına neden olan sey hayvan sunusunun toprak sunusuna tercih edilmesidir. Derrida, bu olayın Batı metafiziği içinde tasarlanmış "hayvan-makine düșüncesinin arketipsel bir örneği olduğunu vurgulamaktadır (2008b: 42-44). Söz konusu arketip, hayvanın insanın emrine sunulmasını ve Tanrının da bu hakkı bizzat insana bahșettiğini gösterir. Bașka bir deyișle, hayvanların ölümü hayatın kabul edilmiş bir parçasına dönüşmektedir; bu söylem, bazen Tekvin 1 : 26 'da gösterildiği gibi bize hayvanlara hükmedebileceğimizi salık veren insan merkezli bir Tanrı tarafından, bazen de üstün insan zekâsının kavramsallaștırma gücü tarafından olușturulmuștur. Adams'a göre, toplum tarafından șșırtıcı olan şey, hayvanın sömürülmesi değil, aksine buna karşı çıkıştır (2013: 139). Bu bağlamda majör kavramların minör kavramlara hâkim olduğu Batı metafiziği ve teolojik inanış, hayvanı tamamen korumasız ve insanın insafına terk etmiştir Nietzsche'nin ata sarılırken hissettiği bu duygusal çöküş, kendini doğaya ve diğer minör öğelere hâkim kılan insanın bencilliğine ve kibrine yönelik gerçekleştirilen bir mit bozumudur. Filmdeki rüzgâr da, adeta mitin bozulduğu anları tek tek ișaretleyen zaman hasatçısı ișlevi yüklenmiștir. Rüzgârın hiç dinmeyen çığlığıyla birlikte, yıkımın mütemadiyen sürdüğü haber verilir. Bu nedenle, Torino Atı filminde esen rüzgâr, etkili bir gösteren olarak, son derecede eskatolojik renkler tașır. Dünyanın sonu ile ilgili kıyamet öğretileri bilimi olan eskatoloji, köklerini mitik ve teolojik anlatılarda bulurken, günümüz modern bilimlerinin kendilerine özgü kıyamet kurguları da bulunmaktadır. Sözgelimi küresel ısınma gibi çağcıl bilimsel inanışlar kıyametin nasıl kopacağına ilişkin profan bir dili yansıtmaktadır. Filmi eskatolojik bir metin haline getiren ahlaki ve moral dekadan ise, ilhamın büyük ölçüde Nietzsche'nin yeni "levhalara yeni değerler yazmayı" vaaz eden put kırıcı girişiminden almaktadır. Antik dünyada ahlaki dekanın doruklara ulaştığı $\mathrm{Ad}$ kavminin benzer bir yok edilme hikâyesine Kuran-ו Kerim'de de yer verilmektedir. Eşcinsel ilişkilerin yaşandığı ve ahlaki yozlaşmanın ayyuka çıktığı Ad kavminin, aynı yerde bir rüzgâr tarafından helak edildiği yazılıdır. Zariyat Suresi'nin 41.- 42 Ayetinde șöyle denmektedir: "Âd'ın bașına gelenlerde de... Onların üzerine uğradığı yeri kasıp kavuran helâk edici bir fırtına gönderdik" (Kur'an-ı Kerim 2003 377). Ahlaki dekadanın dayanılmaz boyutlara gelmiş olması sonucu, Tanrı Ad kavmini bir rüzgârla ortadan kaldırmıştır. Bu katastrofik süreçte rüzgar, metaforik olarak Tanrının yıkıcı enstrümanı olarak işlev görmektedir. Eskatolojik anlatıların çoğunda görülen, Tanrının yıkım sürecinde genellikle tabiat olaylarını -sel, rüzgâr, güneş- kullanışı, Torino Atı filminde rüzgârda somutlaşmaktadır. Bu bağlamda rüzgârın ișlevi fiziksel evrenden taşarak metafizik evrene ulaşmıştır. Öte yandan somut bir cisimden azade olan rüzgârın metafizikleşme süreci fenomonolojik süreçlerle de paralellik arz etmektedir. Merleau Ponty'nin doğa anlayışındaki beden fenomenolojisinin anlattığı șey özünde budur; bedenin varlığa tașma ve doğaya bedenle birlikte katılması benzer bir yörüngede ilerler. Ponty, doğayı ya da doğal dünyayı, şeylerin kendisinde kök saldığı insan dışı doğanın bilinçdışı evren olarak konumlandırmaktadır. Doğa, varoluşun temel bir boyutu olarak insanda verili olan şeyleri tasvir etmektedir. Ponty'ye göre, doğa, hem varoluşun taşıyıc temeli hem de yaşamsal uyumun kendinde yok olduğu temeldir (Dupond 2013: 47). Ponty, insan ve doğa arasındaki denklemi kimi zaman insanın taşıdığı bir yük kimi zaman da evrensel ahengin kendinde yittiği bir uzam olarak kurmuștur. Bu anlamda, Torino Atı'nda ahlaki çöküntüye eşlik eden yıkıcı ve yok edici rüzgâr 
motifi de özünde fenomenolojik olarak ölümün ritmi ve doğanın ortasına fırlatılmış insanın umarsız çığlığıdır. Bu öylesine baş edilmez bir fırlatılmışlık ve yitiklik halidir ki, doğanın kendisi de dâhil, artık insanı fiziksel ve ontolojik açıdan huzura erdirecek hiçbir güvenli dış "kabuk" yoktur.

\section{Issızlığın Ortasındaki Kabuk: “Kulübe”}

Metafiziksel ıssızlaşmanın hüküm sürdüğü ve "dünyaya fırlatılmışlık" halinden güçlü izler taşıyan Torino Atı filmi, aynı zamanda Tanrının varlığı ve mahiyetinin tartışılmasına da kapı aralamaktadır. Tanrının bir töz olarak güven veren varlığı bu filmde silinmekte ve yerini ıssızlığa ve endişelere bırakmaktadır. Ortaçağ'da Tanrı ve varlık üzerine yazan ve ontolojik delilin ilk tasarımcısı olarak kabul edilen Aziz Anselmus, Tanrının varlığını şöyle açıklamaktadır: "illk önce Monologium'un kanıtlarını inceleyelim. Bunlar, iki ilkenin kabulünü varsayarlar: 1Şeyler (Eşya), mükemmellik açısından eşit değildirler; 2- Az ya da çok bir mükemmellik sahibi olan her sey, bunu mutlak anlamda aynı mükemmelliğin parçası olmasından elde eder" (Gilson 2007: 242). Ontolojik olarak mükemmel varlığın özünün en mükemmel şey olan Tanrının varlığını gerektirdiğini belirten Anselmus, Tanrının varlığının rahatlatıcı ve güven verici etkisini örtük de olsa onaylamıștır. Tanrının varlığı ve inanç sistemlerinin ölümü sağaltıcı etkisi, korlașmış ve opaklaşmış karamsarlığı da geçersiz kılmaktadır. Anselmus, ayrıca her şeyin, onun sayesinde iyi olduğu ilkenin ancak büyük bir ilke olabileceğini ve geri kalan her şeyin onun sayesinde iyi olacağını belirtirken, Tanrının da sadece kendisinden dolayı iyi olduğunu dile getirmektedir (Gilson 2007: 242). Filmde yașama, tanrıya ve değerlere ilişkin işaretler silinirken, apokaliptik olaylar öne çıkmaktadır. Kıyametsi meteorolojik olaylar, rüzgârın kesintisiz esmesi, kuyudaki suyun kuruması ve ıssızlık hissi, Nietzsche'ci "Tanrı ölü" ethosunun gerçekliğine gönderme yapmakta gibidir. Bozkırın ortasındaki kulübeye gelince; sığınılacak bir mekândan daha fazlasını çağıştııırken; suyun, gaz yağının ve patatesin giderek azalması, güvenli olan tek yer olan kulübenin tekinsiz bir yere dönüșmesine sözcülük eder. Metaforik olarak kulübe, burada adeta güvenli ana rahminden bir mezar çukuruna dönüşmektedir. Teber, modern insan için tedricen dışarıyla içerinin sınırının izinin kaybolup, giderek kendi üstüne kapanan bir kabuğa dönüșen evin metaforik bir ifadesi olarak, Leibniz'in monad nosyonunu örnek vermektedir: "Homo Sapiens'in" diye yazmaktadır Teber, "evrimleşme süreci içindeki bireysel ruhsal atomlaşmasının metaforik anlatımını Leibniz monad tanımıyla geliștirmiştir. Monad, penceresi, kapısı olmayan, ne içlerine bir şey girebilen ne de çıkabilen bir varlık/mekândır. Aydınlanma döneminin ardından atomize olmuş modern insan, kendi yalnızlığına uygun bir yaşam arayışı içine girdikten sonra Leibniz'in monad tanımını biraz daha derinden anlamaya başlamıştır. Modern insan aydınlandıkça, kendi psişik durumuna, melankolilerine uygun monad tipi kapalı varlık/mekânlara sığınmaya başlamıştır. Bu, kapısız penceresiz iç mekânlar, bu tür uyumsuz insanlar için tek yaşam alanları olarak -yeniden-yapılanmışlardır. Modern yalnız, bu tür bi bağlam içinde, hiçbir sisteme bağlı olmak istemeyen insandır. Ve sığınabileceği/ kaçabileceği tek yer, varlık/mekân, artık kapısız penceresiz bir ev, daha somut bir deyişle, yatak odasıdır" (Teber 1999: 252). Monadın içeriyi ve dışarıyı keskin biçimde ayıran özelliği, onu bir kabuk içinde yeniden şekillendirmektedir. Monad, karanlık bir zemine sahiptir ve ne bir șey dıșarıya gider ne de bir șey dıșarıdan gelir. Ve böylelikle dışının sertliği içeriye hiçbir şeyin sızmamasını sağlar. Hücreler, mezarlar, kilise, tiyatro ya da oyun yeri bu türden dışarının olmadığı, içerinin anlamı ve varlığı belirlediği mekânlardır. Bu bağlamda monad atomdan çok hücreye ve ayin yerine benzemektedir: Bütün etkinliklerin içeride olduğu kapısız ve penceresiz bir oda (Deleuze 2006: 45). Tarr'ın yarattığı mekânın belirgin karakteristik özelliklerinden birisi işte budur, dışarıyla bağlantının olmadığı, içe dönük bir uzam. Bu kapalııı, karakterlerin az konușması ve kișisel trajedilerinde de gözlenmektedir. Filmde sadece üç yerde görülen konuşma sahneleri diyalogdan çok monolog etkisine sahiptir. Dahası söz konusu monologlar da dış dünyada ne olduğuna ilişkin kesin bir bilgi vermekten uzaktır ve baba-kız çiftini ziyarete gelen esrarengiz komșunun ahlaki bakıș açısından yaptığı politik konușma ile atın simgesel ölümü, kuyunun suyunun kuruması ile ışığın sönmesi arasında açık bir koşutluk var gibidir. Asında komşunun attığı ezoterik içerikli tirad, filmin genel atmosferinde yankısını bulan kıyametimsi bir etkiyi açığa vurur. Deyim yerindeyse, bilinmeyen, uğursuz, tekinsiz ve tahripkâr bir gücün temasıdır rüzgârın uğultusu içinde cisimleşmiş olan. Alttan alta varlığı hissedilen bir iblis feryadı... Filmin semantik söz dizimi mecazi niteliktedir. Dahası, komşunun yaptığı konuşma, tabiat olaylarının ve genel yıkımın sonucunda kötülüğün ahlaki düzen üzerindeki nihai zaferi üzerinedir. Ahlaki evrenin düşüşü somut anlamda dünyanın çöküşü demektir (Kovács 2013 149). Filmin altı günlük periyoddan oluşan bölümlemesi, özünde yaratılış anlatısına gönderme yapmakta ve altıncı günün sonunda adeta yaratıışın ters yüz edilmesinin tiradına dönüşmektedir. Bu bağlamda 'ışık olsun' sözüyle başlayan genesis sürecini Tarr altı günlük bir çöküş süreciyle yeniden kurgulayarak ters yüz etmekte ve böylece tartıșmasız biçimde kendi safını belirleyerek, Nietzsche'ci dekadana vurgu yapmaktadır. Issızlığın ortasında bir başına kurtuluş için tek güvenli mekân olan ev -ya da kulübe- giderek ölümün sızdığı bir uzama yataklık etmektedir böylece... Tarr'ın filmografisinde önemli bir yer tutan döngüsellik, bu filmle birlikte en belirgin anlamını kazanmamaktadır. Gündelik hayatın rutin işleyişinde "soluklanan" durağan karakterler, uzun ve karmaşık olmayan kendilerine özgü basit lineer trajedilerini yaşamakta ve bir karşı-yaratımın -ya da yok oluş sürecininiçinde makûs sonlarını beklemektedir (Kovács 2013: 148). Böylece 'Işık olsun' kutsal buyruğuyla başlayan yaratılış eylemi, tedrici olarak, her şeyin gözden yittiği ve en sonda da ışığın söndüğü ters/karşıt yaratıış süreciyle sona ermektedir. Nihayetinde yaratılmıs her sey karanlığa gömülmektedir. Sanki film, bu anlamda yaratıışın fasit dairesidir. Filmde külliyen bir ontolojik aşınma yaşanıp mekân gitgide çölleşirken, baba ve kız hala tek sığınılacak yer olarak kendilerine yaşadıkları kulübeyi görmektedir. Ne var ki, bu ev de karanlığın ve karamsarlığın kapalı yapısına teslim olmakta ve bir monad gibi kapısız, penceresiz mezar çukuruna dönüşmektedir. Sonuçta söz konusu tersine dönmüş yaratıışın (buna belki de yok olus demek daha doğrudur) sonunda ev giderek hiçliğin bilinmezlik uzamı haline gelmekte ve çağrıştırdığı tüm anlamlar ve simgelerle birlikte, ezeli bir karanlığa teslim olmaktadır. Tarr, deyim yerindeyse, sinemaya poetik elvedası 
Torino Atı́nda, evrenin yıkımını Tanrının yaratıcı gücünü de içine alan bir tersine yeniden yazımla işlemektedir. Tanrı-mimar (God-Architecture) hüviyetine bürünmüş olarak, evreni kıyametsi bir vizyon içinden yeniden tasarlamakta ve evrenin çok da kusursuz olmayan işleyişini yeni baştan belirlemektedir. Tanrımimar kavramındaki tanrısal yaratımın özü, evi de içine alan yeni bir evren kavrayışını ortaya koymaktadır. Bilindiği üzere, Hristiyan teolojisi, Tanrılar için mekânlar tasarlarken, Tanrının kendisini de usta bir mimar olarak betimlemektedir. Öte yandan, Heidegger, teknokratik Batı dünyasının yetkin bir eleştirisini yapıp, bozkırın saf ve bozulmayan insanına övgüler yağdırırken, istatistiksel, matematiksel, teknokrat ve kentli Batılı özneyi de eleştirmektedir bir yandan (Sharr 2007: 3). Tasarlayan ve inşa eden Tanrı'nın bir simgesi olan Mimar-Tanrı, böylelikle Torino Atı filminde yıkıCı ve yok edici bir Tanrı'ya dönüşmektedir. Bu yıkıcı Tanrı tasarımı, bir anlamda insanın unutuluşunun/terk edilişinin de göstergesi olup, adeta çarmıhtaki İsa'nın son sözlerine yapılan göndermeyi akla getirmektedir: "Eli eli lema şevaktani" ("Tanrım Tanrım neden beni terk ettin?"). Torino Atı'nın kahramanlarının attığı sessiz çığıı, İsa'nın çığlığına ne kadar da benzemektedir... Nietzsche'nin insanlık tarihinde öldürdüğü de işte bu Tanrı'dır. Tanrı'nın ayrıcalıklı ve birincil mahiyette yarattığı insanın ölümünü ilan eden Nietzsche'nin, bir anlamda Batı aklının yarattığı kanonik düşünceleri aşındırma ve yıkıma uğratma girișiminde bulunmasının ardında da insanın sonsuz bir inmale ve ıssızlığa terk edilmiş durumunda cisimleşmiş olan böyle bir Tanrı'ya duyulan öfke yatmaktadır. Özcesi; insan çağrıştırdığı tüm anlamlar ve değerlerle birlikte ölmüştür. Peki o halde artık insanın sığınacağı yer neresidir? Sophokles "hiç doğmamış olmak belki de nimetlerin en büyüğüdür" der ve bunu der demez hiçlik alanının huzurlu bilinmezliğine teslim olur. Torino Atı filminde bozkırın ortasındaki ev, kuruyan suyu, biten gaz lambası, sönen sobası, pişmeyen patatesler ve bir türlü dinmeyen rüzgârı ile adeta rahatsız edici bir kabuk gibi babayı, kızı ve atı çepeçevre sararken, Sophokles'e hak vermemek mümkün değildir. Filmde evden ve yaşadıkları "imkânları tükenmiş" yerden uzaklaşmak için denemede bulunan baba ve kız, gerek atın 'hastalığı', gerekse rüzgârın karşı koyuşuyla, ancak birkaç yüz metre ilerleyebilmiş olmaları, daha sonra tekrar evlerine dönerek, karşı yaratım sürecinde suyun ve ışığın tükenmesiyle birlikte kendi dramatik sonlarını kucaklamak zorunda kalmaları bunun somut kanıtlarıdır. Öte yandan, zaman ve mekân algısının olmadığı filmde, ev adeta boşlukta rüzgârın da etkisiyle salınıp duran bir "boşluğa" benzemektedir. Baba ve kızın yaşadığı içsel hoşnutsuzluk, hergünkülük cehenneminden ziyade, ruhu karmaşalardan arındırıcı bir tür teselli gibi görünmektedir. Bașka bir deyișle, onlar kendilerini herkesin uyduğu ya da akort ettiği yaşamsal uygunluklara tabi olmalarını gerektirmeyecek yeni bir var kalış biçimi ya da muafiyet hali geliştirmişlerdir: Kendini olayların (rüzgârın) zamansal akışına bırakmak... Filmde ne gizli anlaşmalar ve entrikalar, ne bir gerilim ne de ilișkisel bir ihanet söz konusudur bu yüzden. Her șey, genel bir durgunluk üzere olup bitmektedir sadece, hepsi bu... Dahası, sanki hiçbir şey insan davranışlarının olası sonuçlarına bağlı olarak gerçekleşmemekte, aksine doğanın doğası gereği gerçekleşen işleyişine tabi gibidir. Böylece baba ve kız da gelişen olaylara müdahale etmekten uzak, kendi hayatlarının edilgen birer seyircisi gibi, varlığın dıșsal bir "kabuk"una dönüșmüș olan kulübelerinde, makûs sonlarının geleceği anı bekleyip durmaktadır...

\section{Sonuç}

Denebilir ki, Macar yönetmen Béla Tarr'ın sinemaya poetik elvedası niteliğindeki Torino Atı filmi, öyküsünde insan ilișkilerinin gelișmediği tek filmidir. Temel karakterler olan baba ve kızın birbirleri ile neredeyse hiçbir teması/iletişimi bulunmadığı gibi, aynı şekilde her ikisinin kendilerini kuşatan dış dünyayla da bir ilgileri/iletişimleri yoktur. Baba ve kız birbirleriyle çok az konuşurlar ve konuşmaları mümkün olduğunca en asgari düzeyde olup, genellikle ya babadan kıza ya da kızdan babaya doğru "bildirim amaçlı" bir iletişim şeklindedir. Filmde çok nadir görünen diğer az sayıda karakterlerin de filmin kahramanlarıyla bir ilişkisi bulunmamaktadır. Baba, yerel içki "palinka" satın almak için gelen ve uzun sayılabilecek bir tirat atan komşusuna bile neredeyse tek söz etmez; kendini sadece bir dinleyici olarak konumlar onun karşısında. Aynı şekilde, rahatsız edici bin bir sataşmayla kızını götürmeye çalışan çingeneleri de küfürler savurarak derhal oradan uzaklaştırmaya çalışır baba (Kovács 2013: 148). Bu ve benzeri durumlardan hareketle, denebilir ki, baba ve kız filmde etken özne olmanın aksine doğa olaylarının etkisi altında kalan birer nesneye dönüşmüştür. Baba ve kızın evde pencerenin önünde uzun ve sessiz oturuşları bu edilgenliklerinin ve çaresizliklerinin somut bir örneğidir. Filmde ayrıca baba ve kızın çaresizlikleri kozmogonik bir çöküşle iç içe bir sarmal oluşturur. Bir yandan rüzgârın hayatı çölleştiren etkisi, diğer yandan ıssızlığın ortasındaki bir kabuğu andıran kulübe, hayatın kendisini varoluşsal çaresizliğin ağıtına dönüştürür. Tarr'ın, bir "düşünür-yönetmen" olarak Nietzsche'nin Tanrı'ya ve insana sırt çeviren karamsar tavrını paylaştığı filmi, adeta ölümüne suskun bir atın çağrıştırdığı uğursuz tınılarla, gitgide ıssızlaşan varlığın, yaşamın tekdüze ve apokaliptik yönlerinin karanlığını çarpıcı imgelerle izleyicinin zihnine nakşetmektedir. Tanrı́nın el etek çektiği dünya, artık karanlık demonların ve kötücül güçlerin cirit attığı bir yer haline gelmiş ve baba-kız kendi çaresizlikleriyle örselenmis bir yaşama katlanmak zorunda kalmışlardır. Bu anlamda, Torino Atı, baba-kızın kimliğinde tüm insanlığın kendi karanlık yazgısı içinde attığı sessiz bir çığlıktır. Insan ruhunun en gizli katlarında dolaşan Tarr, deyim yerindeyse, ezoterik duyarlıkların yeraltından bir türlü çıkmak istemez; dahası, karamsarlığın kitonyen topraklarına sığınır. Film, görünüşte yalın ikonografisinin altında çok katmanlı bir anksiyete barındırır. Torino Atı, bu açıdan, sadece Nietzsche'nin delilik nöbetlerine uzaktan da olsa katılmakla kalmaz, deliliğin ölüm ve sessizlikle olan simetrisi de çaresizlik ve tekdüzelik parantezine alınır. Rüzgârın metafiziği kadim bir eskatolojik anlatıyı andırırken, zaman da yaklaşık iki buçuk saat boyunca bilinmez bir dehşetten dolayı kaskatı kesilir. "Işık olsun" kutsal buyruğuyla işlemeye başlayan tanrısal eylem, filmde, adeta yaşayan her şeyi ters yüz olmuş, karşıt bir yaratıış anlatısına dönüştürür. Tarr'ın gayet anlamlı bir biçimde altı güne yaydığı öykü, söz konusu karşıt yaratım sürecinin dehşetengiz etkisiyle, giderek dayanılmaz bir hal alır. Ilkin kuyunun suyu kurur, ardından ocaktaki ateșin közleri birer birer söner, yiyecek biter ve en sonunda da kalan son ışık parçası, soluyan 
karanlık karşısında tümüyle yenik düșer. Böylece "Ișık olsun" ilahi emri "Ișık sönsün" biçimine evrilir. Böylelikle atın yemeyi ve içmeyi reddederek sergilediği büyük reddiye, filmin sonunda kızın yemeyi reddetmesiyle anlamsal bir kurguyla birbirine bağlanır..

\section{Kaynakça}

ADAMS Carol J. (2013), Etin Cinsel Politikası: Feminist-Vejetaryen Eleştirel Kuram, Çev. G. Tezcan- M. E. Boyacıoğlu, İstanbul, Ayrıntı Yayınları.

BAUDRILLARD Jean (2006), Cool Anılar V, Çev. Ayşegül Sönmezay, İstanbul, Ayrıntı Yayınları.

BAUDRILLARD Jean (2006), Kusursuz Cinayet, Çev. Necmettin Sevil, İstanbul, Ayrıntı Yayınları.

CIORAN Emile M. (1999), Tarih ve Ütopya, Çev. Haldun Bayrı, İstanbul, Metis Yayınları.

CIORAN Emile M. (2008), Çürümenin Kitabı, Çev. Haldun Bayrı, İstanbul, Metis Yayınları.

DELEUZE Gilles (2006), Kıvrım, Leibniz ve Barok, Çev. Hakan Yücefer, İstanbul, Bağlam Yayınları.

DERRIDA Jacques (2008a), Çile, Çev. Melih Başaran, İstanbul, Kabalcı Yayınevi. DERRIDA Jacques (2008b), The Animal That Therefor I Am, Edited by MarieLuise Mallet, Trans. David Wills, New York, Fordham University Press.

DUPOND Pascal (2013), Merleau-Ponty Sözlüğü, Çev. Emre Şan, İstanbul, Say Yayınları.

ESKi AHіт, 14. Bap, 21-23. Ayetler, http://www.yaklasansaat.com, (06.02.2014), GILSON Étienne (2007), Ortaçağda Felsefe, Patristik Başlangıçtan XIV. Yüzyılın Sonlarına Kadar, Çev. Ayşe Meral, İstanbul, Kabalcı Yayınevi.

HEIDEGGER Martin (2008), Varlık ve Zaman, Çev. Kaan H. Ökten, İstanbul, Agora Kitaplığı.

KAŞANi Abdürrezzak (2004), Tasavvuf Sözlüğü, Çev. Ekrem Demirli, İstanbul, İz Yayıncılık.

KEARNEY Richard (2012), Yabancılar, Tanrılar ve Canavarlar, Çev. Barış Özkul, İstanbul, Metis Yayınları.

KOVACK András Bálint (2013), The Cinema of Béla Tarr, The Circle Closes, London-New York, Wallflower Press.

KUR'AN-I KERIM (2003), Çev. Mustafa Hizmetli, İstanbul, Erguvan Yayınevi.
LATREILLE Marie-France (2013), "Le Cheval de Turin: Allégorie intemporelle et obsessive...", http://www.dudenfrançais.com, (12.01.2014).

LEVINAS Emmanuel (2011), Maurice Blanchot Üstüne, Çev. Kudret Aras, İstanbul, Monokl Yayınları.

MORICE Jacques (2013), "Le Cheval de Turin", http://: www.telerama.fr, (10.11.2013).

NANCY Jean-Luc (2011), Tanrı Adalet Aşk Güzellik, Çev. Murat Erşen, İstanbul, Monokl Yayınları.

NANCY Jean-Luc (2012), Gitmek/Yola Çıkış, Çev. Murat Erşen, İstanbul, Monokl Yayınları.

NIETZSCHE Friederich (2008), Zerdüşt Böyle Diyordu, Çev. Osman Derinsu, İstanbul, Varlık Yayınları.

REGNIER Isabelle (2011), "Le Cheval de Turin: Magistral final pour Béla Tarr", Le Monde, 29.11.2011

SHARR Adam (2007), Heidegger for Architects, Routledge, USA and Canada.

TEBER Serol (1999), "Homo Sapins'in Kendine Mekân Arayışı Serüveni...", Cogito, Sayı: 18, ss. 250-259.

TURA, Saffet M. (2002), Şeyh ve Arzu, İstanbul: Metis Yayınları.

http://www.lesinrocks.com/cinema/films-a-l-affiche/le-cheval-de-turin, (18.12.2013).

WILLIAMS George M. (2003), Handbook of Hindu Mythology, England, ABCCLIO Inc. 